\title{
¿QUIÉN SOY YO EN ESTE MOMENTO? EXPLORACIÓN DE LAS ACTITUDES DE LOS FUTUROS PROFESORES HACIA LA PROFESIÓN DOCENTE EN MALASIA
}

\author{
WHO AM I THIS TIME? EXPLORING PROSPECTIVE TEACHERS' ATTITUDES \\ TOWARDS THE TEACHING PROFESSION IN MALAYSIA
}

\author{
Bahijah Abas \\ University of Stirling
}

Fecha de recepción: 12 de junio de 2013

Fecha de aceptación: 29 de octubre de 2014

Fecha de publicación: 30 de junio de 2014

\section{RESUMEN}

El presente artículo es un trabajo en progreso de exploración de las actitudes de los futuros profesores hacia la profesión docente en el contexto de Malasia. La identidad profesional se utiliza como una herramienta analítica para comprender la actitud de los futuros profesores. Ashforth y Mael (1989) se refieren a la identidad profesional como la forma en que un individuo trata de determinar su propio grupo profesional en base a lo que ellos consideran común con las características del grupo. El contenido de las características comunes se refieren a varias construcciones profesionales como actitudes y comportamientos que existen en un grupo específico (Haslam, 2001;. Haslam et al 2000; Turner, 1982), así como los valores, habilidades y conocimientos que pueden diferenciar entre la misma y diferente profesión (Glaser-Segura, Mudge, Bratianu y Dumitru, 2010). Una combinación de grupos focales y entrevistas individuales se utilizaron para explorar la percepción sobre "quién soy yo en este momento". 'Tres grupos de futuros profesores se incluyen en el estudio: Alumnos que realizan sus prácticas docentes en las escuelas secundarias de Malasia; Cambio de carrera de alumnos en su último semestre de formación y Alumnos de primer curso de formación docente. Todos los alumnos son de la misma institución de formación docente en Malasia. Todas las entrevistas fueron transcritas y codificadas con el fin de facilitar el desarrollo de categorías analíticas. Se identificaron cinco categorías principales de identidades profesionales: orientación profesional, orientación a la tarea, el compromiso de la enseñanza, la autoeficacia y la interacción social de los futuros profesores. Estas categorías fueron exploradas aún más para identificar las actitudes de los futuros profesores hacia la profesión docente. Además, los resultados también sugieren que el desarrollo de la identidad profesional de los futuros docentes implica un proceso de socialización en contextos formales e informales tales como la influencia de la familia y la sociedad, el entorno socio-económico y la institución educativa.

Palabras clave: Futuros docentes; Actitudes hacia la profesión; Identidad profesional.

\section{ABSTRACT}

This paper is a work in progress exploring prospective teachers' attitude towards the teaching profession in a Malaysian context. Professional identity is used as an analytical 
¿Quién soy yo en este momento? Exploración de las actitudes de los futuros profesores hacia la profesión docente en Malasia

tool to understanding prospective teachers' attitude. Ashforth \& Mael (1989) refer to professional identity as a way an individual tries to determine their own professional group based on what they consider to be common characteristics of the group. The contents of common characteristics refer to several professional constructs such as attitudes and behaviour that exist in a specific group (Haslam, 2001; Haslam et. al 2000; Turner, 1982) as well as values, skills and knowledge that can differentiate between the same and different profession (Glaser-Segura, Mudge, Bratianu \& Dumitru, 2010). A combination of focus groups and individual interviews were used to explore prospective teachers' perception on 'who am I this time?' Three groups of prospective teachers are included in the study: trainees undergoing their teaching practice in Malaysian secondary schools, career change trainees in their final semester of teaching training and first year trainees undergoing their teacher education programme. All trainees are from the same teacher education institution in Malaysia. All interviews were transcribed and coded line-by-line in order to facilitate the development of analytic categories. Five main categories of professional identities were identified: professional orientation, task orientation, commitment of teaching, self-efficacy and social interaction of prospective teachers. These categories were further explored to identify prospective teachers' attitudes towards the teaching profession. In addition, the results also suggest that professional identity development among prospective teachers involves a socialisation process in both formal and informal contexts such as family and society influences, socio-economic environment and educational institution.

Key words: Prospective Teachers; Attitudes Towards Profession; Professional Identity.

\section{INTRODUCTION}

Attitudes is defined as a relatively enduring organisation of beliefs, feelings and behavioural tendencies towards socially significant objects, groups, events or symbols (Hogg \& Vaughan, 2005). Attitudes are organised through experience (Allsup, 1935) and shape over time in relation to the upbringing of the individual and lifelong experiences (Eren, 2001). Regarding these definitions, attitude towards profession can be positive or negative, may or may not change within different contexts and explain individual beliefs, feelings and behaviour towards the specific profession. Individual attitudes towards a profession have an effect on work performance (Wegge, Schmidt, Parkes \& van Dick, 2007). Despite focusing on working people, research on attitude towards the profession has focused on workers-to-be, especially students undergoing their professional training in higher education institutions. This effort seems to be proactive effort for higher education institutions and organisations that will employ those students (Kim, Knight \& Crutsinger, 2009).

Students in higher education may show their attitude towards a certain profession in the way of acceptance or refusal to enter a specific profession (Teng, 2008), or hold favourable or unfavourable attitudes towards the profession (Chen \& Chiu, 2009; Kim, Knight \& Crutsinger, 2009). Teng (2008) found that a group of hospitality students coming back from their internship programme did not show their commitment to 
the job after graduation because of the nature of the job and working conditions. The students found that jobs in hospitality were exhausting, and negatively affect the family and their regular life. In a similar vein, $\mathrm{Kim}$ et al (2009) also found that job characteristics in the retail industry affect students' career intention and their commitment to work. This study found that students that are innovative will choose to work in retail activities that involve decentralised decision making. Kim and colleagues suggest that students will choose the profession that offers job characteristics that fit with their personality. Thus, knowing the attitude to work in a specific profession may provide antecedents and precursors to future workplace performance.

In the teaching profession, prospective teachers' attitudes towards the profession are always being researched. Prospective teachers perceive the teaching profession as a way to assist children learning (Aldemir \& Sezer, 2009) and a noble profession (Hazadiah, 2006); whereas, some others feel that the teaching profession is low in status compared to other professions (Richardson \& Watt, 2005). Attitudes towards the profession might vary in different contexts (Baysal, 1980), hence it could be suggested that reasons that drive the attitudes also might vary in different contexts. In Malaysia, most of the literature suggests that prospective teachers' attitudes towards the profession are related to personality (Halimah Harun, 2006), motive to enter the teaching profession (Suppiah, Hari, Sunder \& Velayudhan, 2012; Othman \& Siti Zafirah, 2010), the influence of the teacher education programme (Muhammad Kamarul \& Raja Ida, 2008), and economic conditions (Othman \& Siti Zafirah, 2010). These constructs focus more towards the teacher education programme. Although Can (1987) suggested that attitudes towards teaching are learned later in life, which points to the importance of teacher education, Cohen-Scali (2003) highlights that every stage in life is important in construction of attitude regarding work, whether it is general or specific information of the professional role. Considering that every stage in life is important to form attitude, the role of the individual as an active participant in their professional choice and activity has to be considered. Attitudes are learnt (Doob, 1947), and during learning processes, individuals will define their self-concept (Olesen \& Whittakar, 1968; Hughes, 1958), or sense of unique identity differentiated from others (Brewer \& Gardner, 1996).

Identity is a concept whereby individuals 'do what they do because of whom they believe they are' (Forte, 2007: 167). It is a cognitive construct that has an influence on individual thought and behaviour (Hogg \& Vaughan, 2005). Hence, many researchers apply the concept of identity as an important analytic tool for understanding school and society (O'Connor, 2008; Carlone \& Johnson, 2007; Sfard \& 
Prusak, 2005; Gee, 2001). As a tool to understand the social phenomena, identity is seen as an on-going proccess that is never completed (Forte, 2007; Cohen-Scali, 2003; Hall, 1987; Watt, 1987) rather than a goal to reach (Hinchliffe \& Jolly, 2011). Stryker \& Burke (2000) suggest that identity can influence individual attitude towards profession in two ways: have a common identification with their professional group and identify their role in professional group. Compared to the latter, professional identity which explains how members of related professions think and place themselves in specific profession group is commonly seen as more salient to the professional, even beyond the professional setting (Abrahamson, 1967).

The aims of this study are to explore prospective teachers' attitudes toward the teaching profession using professional identity as an analytical tool, and examine the process of professional identity formation among them.

\subsection{Defining professional identity}

Professional identity is categorised as one dimension of the social identity, and explains how an individual tries to determine their own occupational group or category membership based on what they consider to be common characteristics of group membership (Ashforth \& Mael, 1989). The contents of those common characteristics often refer to several professional constructs such as attitudes and behaviour that exist in a specific group (Haslam, 2001; Haslam et. al 2000; Turner, 1982) as well as values, skills and knowledge and attitudes that can differentiate between the same and different occupational group (Glaser-Segura, Mudge, Bratianu \& Dumitru, 2010). In the teaching profession, professional identity is used to view teachers' concept or image of self (Knowles, 1992) and this image is built through a long and complex process which begins in childhood (Cohen-Scali, 2003). The process is perceived as complex as it will shape and reshape according to the context (Flores \& Day, 2006; Cohen-Scali, 2003). In sum, professional identity can be viewed as an image or self, influenced by perception of certain characteristics about an individual's professional group. The formation of professional identity involves the continuous and complex process of determining the common characteristics of the specific profession.

\subsection{Professional identity formation}

The term of professional identity in the previous subsection gives a perspective of the role of learning in professional identity development. Learning involves the process of acquiring new or modifying existing knowledge, behaviours, skills, values or preferences. Learning matches 
with the dynamic nature of professional identity formation that has been an influence on the constructivist worldview (Dam \& Bloom, 2006; Niemi, 1997). Learning may occur as part of personal development, education or training, and the learner becomes an information constructor. Scholars posit learning as an active and constructive process, and social in nature (Chi, 2009; Wenger, 1998; Bandura, 1969). Wenger (1998: 4) sees 'learning as social participation, an activity that can be described as being active participants in social communities and constructing identities in relation to these communities'. Back in 1969, Bandura through Social Learning Theory also posits learning as a social process, and suggest that people learn through observation, imitation and modelling. Bandura proposed that from observing others, people form an idea how behaviours are performed, and on later occasions, this coded information will serve as a guide for action. In spite of different methods of learning suggested by Bandura (1969) and Wenger (1998), both learning approaches involve social interaction in forming people's sense of self, or identity.

The process of learning in developing professional identity is associated with professional socialisation that refers to the social learning process by which a person acquires specific knowledge and skills that are required in a professional role (McGowen \& Hart, 1990). The fundamental of the professional socialisation process according to Cohen (1981) is the internalisation of values, norms and ethical standards of professional culture into the individuals' own behaviour and selfconception. Professional socialisation, in the same vein as Forte (2007) and Eraut (1994), focuses the individual as an active participant in developing identity; learning to be professional also begins with a micro level process which is associated with the individual and the process continues with the interaction with the environment until the macro level, which is the institution (Hall, 1987). Similarly, Super (1980) proposed that the individual learns through interaction with the environment and his segmental model draws attention to many sources of learning such as school, society, peer group, community and labour market. Thus, professional identity formation refers to the process of learning about a specific profession and involves a socialisation process within the environment.

The individual may develop their belief regarding the profession from their early childhood experiences and family members. These biographical elements may contribute to the process of professional identity formation (Sugrue, 1997; Knowles, 1992). Family members, especially parents become active agents in inspiring their children on occupational decision making (Sonnert, 2009). Children therefore may choose an occupation and occupational level that match their parents' 
expectation or replicate their parents' occupation. At this stage, children may develop their professional identity in terms of knowledge grounding on the profession.

On the macro level, differences in social, economic and cultural context may have an impact on the image in a certain profession (Kyriacou, Hultgren \& Stephens, 1999). The most influential social factor refers to value that a certain profession holds. Countries that hold Islamic beliefs and culture acknowledged high status on the teaching profession. Teachers who are responsible for disseminating knowledge are seen as having a noble profession and entering the profession gives pride for prospective teachers and their family (Yong, 1995). Thus, individuals who choose to be a member of the teaching profession may do so driven by intrinsic motives. However, as the times change, the virtue of the teaching profession in the Muslim community is suggested to decrease (Mogra, 2010). Some authors find that the motives of prospective teachers in the Muslim community such as in Malaysia and Brunei are moving towards extrinsic motives such as reward (Yong, 1995). While the intrinsic motives of being a teacher exist among prospective teachers, extrinsic motives become more common nowadays, and the shift in these motives is most associated with job condition such as long holiday (Sinclair, 2008) and rewards (Trent, 2011).

Furthermore, school years may have a greater impact for individuals who aspire to the teaching profession. It has been well documented that prospective teachers draw on their experience in education to form their ideas about teaching and construct their selves as a teacher (e.g. Fokken-Bruinsma \& Canrinus, 2012; Struyven, Jacobs \& Dochy, 2012; Trent, 2011). It is assumed that socialisation with teachers in school may inspire children to become a teacher. Teachers cultivate a strong memory for an individual. This assumption is due to findings from a large and growing body of literature in education suggesting the positive relationship of prospective teachers' image and their formal teachers' attitude and behaviour (ibid).

Finally, prospective teachers have to enter the credentialing programme to qualify them to teach. A considerable amount of research has generalised that higher education offers a source of learning for an individual to become a professional (Ezer, Gilat \& Sagee, 2010; Merseth, Sommer \& Dickstein, 2008; Rots \& Alterman, 2008). Individuals therefore are said to have the opportunity to continuously acquire new, or modify existing knowledge, behaviour, value and preferences within the higher education context. This view is somewhat related to Gidden (1991) who claimed that individuals have to engage in a reflexive process of who they are and how they should manage their own definition of self regardless of the context. Thus, higher education 
may be a platform for an individual to construct or reconstruct their professional identity. Following this, while university graduates are generally portrayed as a higher social and occupational group with privileges to better earnings and high social status (Tomlinson, 2007), individuals have to be active participants and to develop or modify their own identity associated with the profession to survive in the world of work.

Several authors call for the implementation of the higher education programme as a source of enhancing knowledge (Dahlgren et al, 2006), skills development (Baddock, Pattison \& Harris, 2010; Sleap \& Reed, 2006) and attitude formation (Taylor \& Pick, 2008; Dahlgren et al, 2006; Sleap \& Reed, 2006). Students' learning in higher education however is influenced by various factors such as learning facilities offered by higher education providers, national education policy imposed to higher education providers (Roselina, 2009; Leathwood \& O'Connell, 2003), higher education providers' philosophies and objectives, prospective employers' expectation (Hinchliffe \& Jolly, 2011; Boden \& Neveda, 2010; Bui \& Porter, 2010), students' interaction with environment (Kaufman \& Feldman, 2004) and their unique expectations, motivations, goals and experiences (Cantwell, 2008). Knowing students' initial motivations to enrol in specific academic programmes helps to identify their progress of person capacity to secure a role in a specific community of practice, and starts to develop their professional identity (Stott et al, 2012).

Knowing the context of professional identity formation is not complete without examining what prospective teachers learn during their socialisation process. To be a professional, occupational knowledge and skills are essential (Krzywacki, 2008). Besides knowledge and skills, values of the teaching profession are also important. Values are defined as desirable motivational goals that operate across context and situation (Schwartz, 1992; Rokeach 1973). Researchers argue that individuals' values are acquired from the socialisation process at every stage of human life including during their participation in higher education (Taber, Hartung \& Borges, 2011; Pike, 2006; Dahlgren, 2005; Berings, Fruyt, Bouwen, 2004).

Additionally, prospective teachers also develop their self-concept during the socialisation process. Self-concept refers to individual assessment of himself/herself. This assessment, however, depends on individual social interaction with the environment (Fulmer, 1972). Contact with other people especially their family members, leads individuals to be able to shape, modify or change their self-concept. Furthermore, the socialisation process develops prospective teachers' feeling on control 
that they have in their profession. Finally, prospective teachers also have an opportunity to develop their emotion. Hargreaves (1998) suggested that teachers should smile even when one is not happy. Following this, Flores and Day (2005) suggest that emotion is crucial to identity formation and emphasise the need for emotional labour - a term introduced by Hochschild (1983). Hochschild argued that common expectation exists concerning the appropriate emotional reactions of individuals in a certain profession. The regulation of emotion in response to these expectations is carried out in two ways: surface acting (changing one's outward emotional expressions without attempting to field the emotion displayed) and deep acting (changing one's outward emotional expressions with attempting to feel the emotion displayed).

One way individuals show their emotion in through empathy. Empathy is the ability to mutually experience the thoughts and emotions of another person. Joirement et. al. (2006) suggest that individuals who showed empathy may exhibit altruism, civic virtue, conscientiousness and courtesy. Sense of empathy can be investigated through cognitive empathy, which relates to an individuals' capacity to understand another person's perspective rather than being exclusively self-oriented (Hogan, 1969). Thus, individuals' ability to be pleasant, charming, friendly, cheerful, sociable, sentimental, imaginative, discreet and tactful may describe their sense of empathy. In the learning process, sense of empathy will help individuals to develop their awareness towards other people (Choi \& Yang, 2011).

In sum, professional identity formation involves a socialisation process in different contexts, and a variety of learning outcomes.

\section{THE RESEARCH CONTEXT}

This study was conducted in Malaysia. Malaysia is a multiracial country consisting of Malays (the majority), Chinese, Indians and other small groups such as Sikhs. Islam is the national religion and all Malays are Muslims, but other major religions practised include Buddhism, Hinduism, Christianity and Taoism. As a country that has a majority Muslim population, the religious and cultural values of Islam have a significant impact on social policy and practice including in education (Rassool, 2000). Following this, the position of teacher in Malaysia is influenced by religious and cultural values of Islam. A teacher is recognised as a knowledgeable person and Islam gives high rank to the knowledgeable person as stated in the Al- Quran (sacred book for the Muslims). A knowledgeable person is assumed to be able to disseminate knowledge and positive values, and make other people better with their effort on 
teaching. Teachers are afforded high esteem and are viewed as role models and respected community leaders (Mogra, 2010). By being a role model, teachers also are expected to exemplify in their life the content of what they taught (Minnis, 1999). Therefore in Islam, there are no other professions that can compete in terms of virtue with the teaching profession (Mogra, 2010).

\subsection{Important term}

Secondary school teachers in Malaysia must have at least a degree in education to qualify them to teach. In this study, prospective teachers refer to students that are undergoing a teacher education programme in the biggest secondary teacher training institution in Malaysia. The teacher training institution offers a degree in education in various fields (language, special education, moral education, geography, history, Islamic education and many others). The minimum duration is four years and the curriculum consists of classroom teaching and learning, teaching practice in selected secondary schools and undergraduate dissertation. Admission to this programme is controlled by the Ministry of Education. Students graduating with a minimum cumulative average grade of 2.75 points over 4.00 points are qualified to apply for the post of secondary school teacher. Candidates who are successful in the teacher selection process may have their posting in selected public secondary schools throughout Malaysia thereafter (Ministry of Education Malaysia, 2010).

\section{METHODS}

\subsection{Research participants}

A purposive sample of 112 prospective teachers was selected for this study. This study was conducted in the state of Perak. Perak is situated in west Malaysia and the selection of this state is made because at the time of the study, Perak had the biggest number of prospective teachers undergoing their teaching practice, hence provided a good distribution of different programmes of study. In the initial stage of data collection, I went to a group of prospective teachers undergoing their teacher training in one urban secondary school in the state of Perak. This group was chosen because they represent students from different programmes of study: Business Administration, Art, Moral Education and Special Education. After conducting a focus group discussion for this group, I find more groups that can further explain the theme derived from previous focus group discussions. This iterative procedure continues until there are no more new themes emerging from the discussions. 
The iterative procedure brings in a second group of participants. Participants in the second group consist of 13 prospective teachers. They come from diverse occupation backgrounds; administrator, trainer and some of them have been school teachers as untrained or substitute teachers. Untrained or substitute teachers teach a school class when the regular teacher is unavailable because of illness, maternity leave or other reasons. They will be in school for a short time. Finally, a third group of participants are included in the study. This group consists of 12 prospective teachers in their first semester of the teacher education programme. Four participants from the focus group discussions also voluntarily participated in in-depth interviews.

\subsection{Data gathering}

Two methods were used to gather data from prospective teachers: focus group and individual interview.

1) Focus group discussion

The first method was to conduct focus group discussions among three groups of prospective teachers. The advantages of conducting focus group discussions are participants have the opportunity to learn from each other and develop ideas together (Jackson, 2003). Additionally focus group discussions encourage group interaction to produce data and insights that would be less accessible without interaction found in a group (Morgan. 1997). As a moderator, I create a permissive environment in the group that encourages participants to share perception, and their point of view without pressuring them to vote or reach consensus. The discussion is also open and unstructured to allow the emergence of themes from the participants.

2) Individual interview

Individual interview is conversation with a specific purpose - a conversation to get details on participants' perception of self, teacher self life and experience to become a teacher. Each interview was recorded, transcribed and analysed.

\subsection{Data analysis}

The computer package NVivo 9 was used to help organise and manage the data and the analysis. Data were derived from group and in-depth interviews. I used interview coding to capture what is in the interview data to learn how the respondents (prospective teachers) make sense of their experience and act on them. The details of the coding process are as follows: 1) Open coding/line by line coding is used to identify initial phenomena and produce a list of themes of importance 
to the respondents. Most of the themes' labels are taken from respondents' own words - in vivo code. Open coding helps me to interpret the interview transcripts in new and unfamiliar ways. 2) Focused/selective coding allowed me to create and try out categories for capturing data. I have applied these focused codes on further interview transcripts. This process helps me to develop a conceptual framework. 3) Axial coding aims to add depth and structure to existing categories. This is an on-going process, and I am still working on this coding. I am following Strauss \& Corbin's (1998) work on developing categories, and they suggested that axial coding will investigate further conditions of situations described in the interview as well as their actions and consequences. I believe that this type of coding can help me to identify many issues that are important to the respondents, thus will provide a basis for developing a theory.

\section{FINDING}

This section reports on the initial finding of this study. There are two main findings: categories of prospective teachers' professional identity and process of professional identity formation.

\subsection{Categories of prospective teachers' professional identity}

1) Professional orientation

Participants' determination of their occupational group with the values, knowledge and skill lead the first category of professional orientation. Professional orientation refers to one's important role in their profession. They perceived themselves as extended or restrictive teachers. Research participants mostly build their professional orientation by value in the teaching profession.

Teacher DPLI

"Teachers nowadays are not restricted to serve students only at school. It is a 24 hour job. I mean teachers should be willing to assist students even in out of school time. Out of classroom. It is what teachers are for"

\section{Teacher BJl}

"It is very enjoyable being a teacher. It is not a routine job. You think something new every day in order to help students develop themselves".

The conception of extended profession as introduced by Hoyle (1974) can be used to explain these new roles. According to Hoyle (1969), the teachers' role is traditionally perceived to place emphasis on 
moral training and instruction. The teacher has a greater autonomy on what and how to teach in the classroom. Traditional teachers' core professional activities were focused on immediate responsibilities and classroom concern. Hoyle (1974) referred to this group of teachers as involved in a restricted profession. On the other hand, due to educational changes such as in technology and curriculum, teachers' roles are not limited to the classroom. The teacher now needs to acquire a wide range of knowledge and skills to cope with the new demand. Hoyle (1974) termed these new characteristics of responsibility as extended profession.

\section{2) Task orientation}

Research participants explain 'what do I want to achieve with my pupils and how do I want to do this?' Task orientation is more specific compared to professional orientation. Task orientation is most likely influenced by occupational knowledge and skills, emotion, value and autonomy of teachers.

Prospective teachers agree that their main client is students. As a teacher, they are responsible for the students academically and their wellbeing. Participants say that they are not keen on the traditional approach of teaching where teachers only transmit knowledge and provide the correct solution about teaching. Teachers primarily see their role as a facilitator for students who seek out solutions by themselves. Their approach is more towards constructivism, where they let the student generate their own idea through discussion and one to one learning.

Teacher SK8 - teaching practice

"I am from Malay Language Education programme. Yes, almost $100 \%$ of students in my class are Malay native speakers yet they are not using correct sentence structure in their essays. They also don't know how to structure the essays! They asked me to provide a generic essay structure for everyone. I said, no. Don't be too rigid. Come out with your own structure and write accordingly. Be creative. I can help them individually to develop their ideas. Providing a structure for students can't help them develop their own critical thinking."

Teacher TIWA I- teaching practice

"Even though I am in my teaching training, I rarely use text or reference books in my class. I don't want my student to rely only on books that were written two or three years back. I am using current newspaper cuttings. Let's say, in a syllabus, students should know about landslides. We got landslide phenomena over here (Malaysia). Give students relevant paper cutting, ask them to try to understand what was 
written by the reporter on that phenomena, think and tell their friends what they think caused the landslide. Discuss! I believe students will remember what they are discussing rather than reading from a book, and try to understand."

Constructivism can help students to explore new ideas and come up with creative solutions, apply cooperative learning with peers and encourage long time understanding (Hardy, Jonen, Moller \& Stern, 2006). Teachers who apply constructivism paradigm for teaching and learning need to recognise their students' ability to learn, be creative in choosing teaching material and provide strong guidance for student learning (Kirschner, Sweller \& Clark, 2006).

\section{3) Self-efficacy}

Prospective teachers explained their capabilities to bring about desired outcomes of student engagement and learning, even among those students who may be difficult and unmotivated. Participants are also concerned about students with academic disability. According to them, every student has their own potential and must be taught evenly. If they are a fast learner, the teacher will apply different kinds of teaching methods compared to slow learners. It is sad to say that in certain rural areas, at the age of 13, there are some school students that do not have the ability to read and write. This group of people however are encouraged to go to mainstream schools. Sometimes this group of students will be sent to vocational class where they can learn some skills to continue their life after school. For this kind of student, the teachers try different types of teaching methods in order to provide meaningful learning for them.

Teacher TIWA l - teaching practice

"I asked senior teachers what should I do to the students that are left behind academically. They said - used your creativity, or just teach them as you teach other students. Oh! I should teach them in a way that they will understand. I start surfing on the internet on what can be used to facilitate the teaching and learning process. I teach geography. When it comes to types of seasons, I download movies that have a scene of winter, autumn, spring and summer, wet and hot; and asked students to 'feel' the seasons. It works! There's no snow in Malaysia but the student can feel the coldness from James Bond movie!"

Teacher SP3 - teaching practice

"I think that I am lucky because I can meet with students with low literacy skills. They are a normal person, but may not have an opportunity to learn in a proper way. That's a challenge for me. I teach commerce subject here. Yes, sometimes I teach them how to write properly, but I 
¿Quién soy yo en este momento? Exploración de las actitudes de los futuros profesores hacia la profesión docente en Malasia

am a commerce subject teacher. I've a responsibility to deliver my content knowledge. Let's learn by doing, not by telling. We do practical things during teaching and learning session. Barter system? Don't tell them, they won't listen. Just do it".

Besides teaching the subject matter, teachers are very happy to motivate their students during their contact hours. This motivation comes from teachers' own experience whereby most of the teachers feel the same experience when previously at school. They sincerely motivate students and give them moral support, whether academically or in their social life.

Teacher SK4 - teaching training

"For me, if the students don't have a capability in academic achievement, or are experiencing learning difficulties, that is not the end of the world. There are a lot of opportunities for this group of students. I like the proverb - Don't give a fish to our student. Teach them how to fish and they can use the skill forever. Motivate them, give them appropriate skills".

Teacher BK 1 - teaching training

"I am quite happy if I can motivate my students to be a better person spiritually. Be a good person. At least if they are not performing well academically, they still can become a good person".

Teacher TIWA5 - teaching training

"Unfortunately, I got a class full of 'undesired students' in school. They are not capable academically or in respect to teachers. Speechless. But I have to do something because I am in my teaching training! I don't want to fail my internship course. I try very hard to be their friend, not the teacher. I found that this group of students are very creative. They have been left out because they did not get any 'A's in their subject. School nowadays really focuses on academic aspects. We try to do something that will make the school proud of us. We did it! We make a mural, and won a competition in recycling campaign. Aha, I realise that the students only need attention and motivation".

Teachers are keen to help students because they can identify and understand students' situation, feeling and motives.

Teacher DPLI25

"I was punished by my former teacher because I did not finish my homework. Yes, that is my fault. But I had a reason. My father was sick and I helped my mother to look after him. My teacher never asked. Just punished!" 
Teacher TP7

"In secondary school, I was among the low achievers academically. Most of the teachers ignored the low achievers because the just pay attention to high achievers. Very sad. Not excellent academically does not mean that you are useless".

4) Commitment to teach

Participants explain the extent to which they feel psychologically connected to the teaching profession.

They also believe that they should have good interpersonal skills. Having a good relationship with students means that they will be able to solve the students' problem individually.

\section{Teacher AB2}

"Teachers should have a close relationship with students. We spend almost six hours together"

Some prospective teachers are not interested in the teaching profession. They enter teacher education not by choice but to fulfil their family's aspiration.

\section{Teacher AB7}

"I do not love teaching job. Nonetheless, I consider myself as a responsible person. I do my work, I prepare my teaching material, I teach students the content of the subject - yet I do that for nothing. I am just responsible for my title as a teacher."

\section{Teacher HD2}

"Teaching is not my first choice, yet it is a secure profession. Schools are everywhere, young generations need to go to school, so I will still have a job. If I will be posted in any school, I will do my job as stated in the job description. I will do that because I have to do that. Children need to learn something from school. I will make sure they will learn something"

Even though some of the prospective teachers are not interested in the profession, they still keep the positive reputation of the teaching profession.

5) Society interaction

Participants clarify their role towards society - what they give to society and vice versa. They perceived themselves as agents for 
¿Quién soy yo en este momento? Exploración de las actitudes de los futuros profesores hacia la profesión docente en Malasia

delivering universal values that are important for living in collective society.

Teacher AB3

"Parents and society are schools' clients. They should have confidence with services offered by the school. They invest their 'belief' that a teacher will educate their children. Yes, we will. Tell them we will."

Teacher HD2

"Student - teacher relationship is not only applicable in school, but outside the school environment. I don't mind if students come to my house and ask about homework. It is for their own sake".

\subsection{Process of professional identity formation}

The majority of participants tend to refresh their memory with their teacher, and agree that teachers are the students' role models. Examples of perception that the teacher is the students' role model are noted below:

Teacher AB5 - teaching training

"Don't blame students if they are not listening to teachers. Ask yourself what have we (teachers) done to students that causes them to behave so".

Teacher SK4 - teaching training

"We (teachers) want to educate students. Are we ready? Are we educated enough so that we can educate other people?"

Participants also mention what they should do when they perceived that teachers are the students' role models.

Teacher TIWA 1 - teaching training

"Teaching is not only about subject matter. Teaching is not only a process of verbal communication. It involves non-verbal communication too. How we dressed up in front of students, our image."

Teacher TP9

"be careful of our words, our moral".

The majority of the participants share experience with their teacher. Their teacher images in general have been based on their memories of their teachers; their mannerism and the way they taught.

Teacher AB2 
"He (previous teacher) is not actually a teacher! He brings all his personal problems in the classroom. He attacks students! What kind of teacher is like that! I promise that I will be a good and nice teacher and I will not let that kind of person enter the teaching profession. Never."

Teacher HDI

"If you asked me who inspired me to be a teacher, I proudly announce that I want to be a teacher because I love my teachers. They are all very committed in education, they never give up, they always smile. What else do you want from a teacher? I will continue this tradition. I will. My students will have a committed teacher, never give up and always smile."

To date, the findings of professional identity formation suggest that previous teachers affect prospective teachers' development to become a teacher.

\section{CONCLUSION}

This paper reports the findings of a work in progress doctoral study that explored prospective teachers' attitude toward the teaching profession in Malaysia. Professional identity was used to understand prospective teachers' attitude. To date, the findings of this study would suggest that there are five categories of professional identity: professional orientation, task orientation, commitment of teaching, selfefficacy and social interaction of prospective teachers. These categories will be further explored to identify prospective teachers' attitude towards the teaching profession, whether they hold a positive or negative attitude and the common attitude among all participants. The next stage of this study will continue with examining the social theory that will explain the professional identity process.

\section{REFERENCES}

Abrahamson, M. (1967). The professional in the organisation. Chicago: Rand McNally.

Aldemir, J. \& Sezer, O. (2009). Early childhood education pre-service teachers' images of teacher and belief about teaching. Inonu University Journal of The Faculty of Education, 10(3), 105-122.

Allport, G. W. (1935). Attitudes. In Handbook of social psychology, ed. C. Murchison, 789 - 844. MA: Clark University Press.

Ashforth, B. E. \& Mael F. (1989). Social identity theory and the organisation. Academy of Management Review, 14(1), 20 -39. 
Badcock, P. B. T., Pattison, P. E. \& Harris, Kerri-Lee (2010). Developing generic skills through university study: a study of arts, science and engineering in Australia. Higher Education, 60, $441-458$.

D.O.I.: http://dx.doi.org/10.1007/s10734-010-9308-8

Bandura, A. (1969). Social Learning Theory of identificatory processes. In Handbook of Socialization Theory and Research.

Berings, D., Fruyt, F. D., \& Bouwen, R. (2004). Work values and personality traits as predictors of enterprising and social vocational interests. Personality and Individual Differences, 36, $349-364$.

D.O.I.: http://dx.doi.org/10.1016/50191-8869/03)00101-6

Boden, R. \& Nedeva, M. (2010). Employing discourse, universities and graduate 'employability'. Journal of Education Policy. 25(1), 37 54. D.O.I.: http://dx.doi.org/10.1080/02680930903349489

Brewer, M. B. \& Gardner, W. (1996). "Who is this we"? Levels of collective identity and self-representations. Journal of Personality and Social Psychology, 71, 83-93. D.O.I.: http://dx.doi.org/10.1037/0022$\underline{3514.71 .1 .83}$

Bui, B. \& Porter, B. (2010). The expectation-performance gap in accounting education: An exploratory study. Accounting Education: An International Journal. 19, 23 - 50.

D.O.I.: http://dx.doi.org/10.1080/09639280902875556

Baysal, A. C. (1980). Theoretical concept of attitude, a practical method and a research sample about attitude towards work in business. Unpublished PhD theses. Istanbul University.

Can, G. (1987). A study on the understanding of teaching profession (in school of Ankara). Journal of Anadolu University Education Faculty 2: $159-170$.

Cantwell, A. M. (2008). Linking undergraduate value orientations to student academic behaviours. Centre for Studies in Higher Education.

Carlone, H. B. \& Johnson, A. (2007). Understanding the science experiences of successful women of color; Science identity as an analytic lens. Journal of Research in Science Teaching, 44(8), 1187 - 1218. D.O.I.: http://dx.doi.org/10.1002/tea.20237

Chi, M. T. (2009). Active-constructive-iterative: A conceptual framework of differentiating learning activities. Topics in Cognitive Science, 1(1), $73-105$.

D.O.I.: http://dx.doi.org/10.1111/j.1756-8765.2008.01005.x

Chen, Chien-Cheng \& Chiu, Su-Fen (2009). The mediating role of job involvement in the relationship between job characteristics and organizational citizenship behavior. The Journal of Social Psychology, 149(4), $474-494$.

D.O.I.: http://dx.doi.org/10.3200/SOCP.149.4.474-494

Cohen, H. A. (1981). The nurse's quest for a professional identity. AddisonWesley, California 
Cohen-Scali, V. (2003). The influence of family, social, and work socialisation on the construction of the professional identity of young adult. Journal of Career Development, 29(4), 237 - 249.

D.O.I.: http://dx.doi.org/10.1177/089484530302900402

Dahlgren, M. A. \& Chiriac, E. H. (2009). Learning for profesional life: Students teacher' and graduated teachers' view of learning, responsibility and collaboration. Teaching and Teacher Education, 25, 991 - 999. D.O.I.: http://dx.doi.org/10.1016/j.tate.2009.03.019

Dahlgren, M. A., Hult, H., Dahlgren, L. O., Segerstad, H H af., \& Johansson, K. (2006). From senior student to novice worker; Learning trajectories in political science, psychology and mechanical engineering. Studies in Higher Education, 31 (5), 569 - 586.

D.O.I.: http://dx.doi.org/10.1080/03075070600923400

Dam, G. T. M. \& Blom, S. (2006). Learning through participation. The potential of school-based teacher education for developing a professional identity. Teaching and Teacher Education. 22, 647 660. D.O.I.: http://dx.doi.org/10.1016/j.tate.2006.03.003

Doob, L. W. (1947). The behaviour of attitudes. Psychological Review, 54(3), 135. D.O.I.: http://dx.doi.org/10.1037/h0058371

Eraut, M. (1994). Developing professional knowledge and competence. London: Falmer.

Eren, E. (2001). Organisational behaviour and management psychology. 7 Ed. Istanbul: Beta Publication.

Ezer, H., Gilat, I., \& Sagee, R. (2010). Perception of teacher education and professional identity among novice teachers. European Journal of Teacher Education, 33(4), $391-404$

D.O.I.: http://dx.doi.org/10.1080/02619768.2010.504949

Flores, M. A. \& Day, C. (2006). Context that shape and reshape new teachers' identities: A multi-perspective study. Teaching and Teacher Education, 22, $219-232$.

D.O.I.: http://dx.doi.org/10.1016/j.tate.2005.09.002

Fokkens-Bruinsma, M. \& Canrinus, E. T. (2012). Adaptive and maladaptive motives for becoming a teacher. Journal of Education for Teaching: International Research and Pedagogy, 38(1), 3 - 19.

Forte, R. F. (2007). A review of professional identity theory with implications for training and development. Journal of European Industrial Training, 31 (3), 166- 180.

D.O.I.: http://dx.doi.org/10.1 108/03090590710739250

Gee, J.P. (2000). Identity as an analytic lens for research in education. Review of Research in Education, 25, 99 - 125.

Giddens, A. (1991). Modernity and self-identity. Cambridge: Polity Press.

Glaser-Segura, D. A., Mudge, S., Bratianu, C. \& Dumitru, I. (2010). Development of professional identity in Romanian business students. Education + Training, 52(3), $198-213$.

D.O.I.: http://dx.doi.org/10.1108/00400911011037337 
¿Quién soy yo en este momento? Exploración de las actitudes de los futuros profesores hacia la profesión docente en Malasia

Halimah Harun (2006). Minat, motivasi dan kemahiran mengajar guru pelatih. Jurnal Pendidikan, 21, 83-96.

Hall, D. T. (1987). Careers and socialisation. Journal of Management, 13(2), 301-321.

D.O.I.: http://dx.doi.org/10.1177/014920638701300207

Hardy, I., Jonen, A., Moller, K., \& Stern, E. (2006). Effects of instructional support within constructivist learning environments for elementary school students' understanding of 'floating and sinking'. Journal of Educational Psychology, 98(2), 307.

D.O.I.: http://dx.doi.org/10.1037/0022-0663.98.2.307

Haslam, S. A. (2001). Psychology in organisation: The Social Identity Approach. Sage : London.

Haslam, S. A., Turner, J. C. \& Turner, J. C. (2000). Social identity, selfcategorisation, and work motivation: Rethinking the contribution of the group to positive and sustainable organisational outcome. Applied Psychology: An International Review, 49:319- 339.

D.O.I.: http://dx.doi.org/10.1111/1464-0597.00018

Hazadiah Mohamad Dahan \& Siti Salina Ghazali (2007). How does it feel to be a teacher? Personal journeys and lessons for a Malaysian university. Asian Journal of University Education, 3( 1), 63 - 80.

Hargreaves, A. (1998). The emotional practice of teaching. Teaching and Teacher Education, 14(8), $835-854$.

D.O.I.: http://dx.doi.org/10.1016/50742-051x(98)00025-0

Hinchliffe, G. W \& Jolly, A. (2011). Graduate identity and employability. British Educational Research Journal, 37 (4), 563 - 584.

D.O.I.: http://dx.doi.org/10.1080/0141 1926.2010.482200

Hogg, M. A. \& Vaughan, G. M. (2005). Social Psychology. 4th edition. Pearson Education Limited: UK.

Hochschild, A. R. (1983). The managed heart: Commercialisation of human feeling. Berkeley: University of California.

Hogan, R. (1969). Development of an empathy scale. Journal of Consulting and Clinical Psychology, 33(3), 307-316.

D.O.I.: http://dx.doi.org/10.1037/h0027580

Hoyle, E. (1974). Professionality, professionalisme and control in teaching In Professionalisation and deprofessionalism in education (2012). World yearbook of education.

Hoyle, E. (1969). The role of teacher. London: Routledge \& K. Paul.

Hughes, E. C. (1958). Men and their work. New York: New York Free Press.

Jackson, W. (2003). Methods: Doing Social Research (3rd edition), Canada: Prentice Hall.

Joireman, J., Kamdar, D., Daniels, D. \& Duell, B. (2006). Good citizens to the end? It depends; Empathy and concern with future consequences moderate the impact of the short-term time horizon on organizational citizenship behaviours. Journal of Applied Psychology, $91(6)$, 1307-1320. 
D.O.I.: http://dx.doi.org/10.1037/0021-9010.91.6.1307

Kaufman, P. \& Feldman, K. A. (2004). Forming identities in college: A sociological approach. Research in Higher Education, 45(5), 463 496. D.O.I.: http://dx.doi.org/10.1023/B:RIHE.0000032325.56126.29

Kirschner, P. A., Sweller, J. \& Clark, R. E. (2006). Why minimal guidance during instruction does not work: An analysis of the failure of constructivist, problem based, and inquiry-based teaching. Educational Psychologist, 41, 75 - 86.

D.O.I.: http://dx.doi.org/10.1207/s15326985ep4102_1

Kim, H., Knight, D. K. \& Crutsinger, C. (2009). Generation Y employees' retail work experience: The mediating effect of job characteristics. Journal of Business Research, 62, $548-556$.

D.O.I.: http://dx.doi.org/10.1016/i.jbusres.2008.06.014

Knowles, G. J. (1992). Model for understanding pre-service and beginning teachers biographies: illustrations from case studies. In study teachers' life. Ed Goodson I. F London : Routlied teachers life.

Krzywacki, H. (2009). Becoming a teacher: Emerging teacher identity in mathematics teacher education. Academic Dissertation, University of Helsinki, Finland.

Kyriacou, C., Hultgren, A. Stephens, P. (1999). Students teachers' motivation to become secondary school teacher in England and Norway. Teacher Development, 33(1), 373 - 381.

D.O.I.: http://dx.doi.org/10.1080/13664539900200087

Leathwood, C. \& O'Connell, P. (2003). 'It's a struggle': the construction of 'new student' in higher education. Journal of Education Policy, 18(6), 597-615

D.O.I.: http://dx.doi.org/10.1080/0268093032000145863

McGowen, K. R. \& Hart, L. E. (1990). Still different after all these years: Gender differences in professional identity formation. Professional Psychology: Research and Practice, 21 (2), $118-123$.

D.O.I.: http://dx.doi.org/10.1037/0735-7028.21.2.118

Merseth, K. K., Sommer, J. \& Dickstein, S. (2008). Bridging worlds: Changes in personal and professional identities of pre-service urban teachers. Teacher Education Quarterly, 89 - 108.

Ministry of Education Malaysia. www.moe.edu.my

Minnis, J. R. (1999). Is reflective practive practice compatible with MalayIslamic values? Some thoughts on teacher education in Brunei Darussalam. Australian Journal of Education, 43,172 - 185.

D.O.I.: http://dx.doi.org/10.1177/000494419904300206

Mohamed Najib Abdul Ghafar \& M Noor Ariffin (2008). Kesan latihan perguruan ke atas faktor pemilihan guru. Jurnal teknologi, 48(E), 15 -31 .

Morgan, D. L. (1997). Focus groups as qualitative research. California: SAGE Publication Inc. 
¿Quién soy yo en este momento? Exploración de las actitudes de los futuros profesores hacia la profesión docente en Malasia

Muhammad Kamarul Kabilan \& Raja Ida Raja Izzaham (2008). Challenges faced and the strategies adopted by a Malaysian English Language teacher during teaching practice. English Language Teaching, 1(1), 87 - 95

D.O.I.: http://dx.doi.org/10.5539/elt.v1n 1 p87

Mogra, I. (2010). Teachers and teaching: A contemporary Muslim understanding. Religious Education: The Official Journal of the Religious Education Association, 105(3), 317 - 329.

D.O.I.: http://dx.doi.org/10.1080/00344081003772089

Niemi, P. M. (1997). Medical students' professional identity: self-reflection during the preclinical years. Medical Education, 31, $408-415$ D.O.I.: http://dx.doi.org/10.1046/j.1365-2923.1997.00697.x

O'Connor, K. E. (2008). "You choose to care": Teachers, emotions and professional identity. Teaching and Teacher Education, 24, 117 126. D.O.I.: http://dx.doi.org/10.1016/j.tate.2006.11.008

Olesen, V. L. \& Whittaker, E. W. (1968). The silent dialogue: A study in the social psychology of professional socialisation. CA: Jossey-Bass

Othman Md Johan \& Siti Zafirah Mohd Ilias (2010). Pemilihan profesion perguruan di kalangan pelajar. Journal of Educational Science

Pike, G. R., Smart, J. C., \& Ethington, C. A. (2012). The mediating effects of student engagement on the relationships between academic disciplines and learning outcomes: An extension of Holland's Theory. Research in Higher Education, 53, 550 - 575.

D.O.I.: http://dx.doi.org/10.1007/s $11162-011-9239-y$

Rassool, G. H. (2000). The crescent and Islam: healing, nursing and spiritual dimension. Some considerations towards an understanding of the Islamic perspectives on caring. Journal of Advanced Nursing, 32(6), $1476-1484$.

Richardson, P. W. \& Watt, H. M. G. (2005). 'I've decided to become a teacher': Influences on career change. Teaching and Teacher Education, 21, $475-489$.

D.O.I.: http://dx.doi.org/10.1016/i.tate.2005.03.007

Rokeach, M. (1973). The nature of human values. New York: The Free Press

Roselina Shakir (2009). Soft skills at the Malaysian institute of higher learning. Asia Pacific Education Review, 10, $309-315$.

D.O.l.: http://dx.doi.org/10.1007/s12564-009-9038-8

Rots, I. \& Aelterman, A. (2008). Two profiles of teacher education graduates; A discriminant analysis of teaching commitment. European Educational Research Journal, 7(4), 523- 534.

D.O.I.: http://dx.doi.org/10.2304/eerj.2008.7.4.523

Sfard, A. \& Prusak, A. (2005). Telling identities: In search of an analytic tool for investigating learning as a culturally shaped activity. Educational Researcher. 34(14). 14- 22.

D.O.I.: http://dx.doi.org/10.3102/0013189X034004014 
Sinclair, C. (2008). Initial and changing student teacher motivation and commitment to teaching. Asia Pasific Journal of Teacher Education, 36(2), 79 - 104.

D.O.I.: http://dx.doi.org/10.1080/13598660801971658

Sleap, M. \& Reed, H. (2006). View of sport science graduates regarding work skills developed at university. Teaching in Higher Education, 11 (1), 47 - 61. D.O.I.: http://dx.doi.org/10.1080/13562510500400123

Stott, T., Zaitseva, E., \& Cui, V. (2012). Stepping back to move forward? Exploring outdoor education students' fresher and graduate identities and their impact on employment destinations. Studies in Higher Education, 1 - 23.

Struyven, K., Jacob, K. \& Dochy, F. (2012). Why do they want to teach? The multiple reasons of different groups of students for undertaking teacher education. European Journal of Psychology Education.

Stryker, S. \& Burke, P. J. (2000). The past, present and future of an identity theory. Social Psychology Quarterly, $284-297$.

D.O.I.: http://dx.doi.org/10.2307/2695840

Sugrue, C. (1997). Students' teachers lay theories and teaching identities: Their implications for professional development. European Journal of Teacher Education, 20(3), $213-225$.

D.O.I.: http://dx.doi.org/10.1080/0261976970200302

Super, D. E. (1990). A life-span, life-space approach to career development, In Brown, D. \&Brooks, L. career choice and development, San Francisco, CA: Jossey-Bass.

Suppiah Nachiappan, Hari Krishnan Andi, Sunder Subbramaniam \& Velayudhan P. K. Veeran (2012). Factors that motivates the teacher trainees of teacher training institutions to possess an excellent personality through hermeneutic analysis method. Journal of Educational and Developmental Psychology, 2(2), 97 104. D.O.I.: http://dx.doi.org/10.5539/jedp.v2n2p97

Schwartz, S. H. (1992). Universal in the content and structure of values: theoretical advances and empirical test in 20 countries, In Advances in experimental social psychology edited by Zanna M. P. San Diego: Academic Press Inc.

Taber, B. J., Hartung, P. J., \& Borges, N. J. (2011). Personality and values as predictors of medical specialty choices. Journal of Vocational Behaviour, 78, $202-209$.

D.O.I.: http://dx.doi.org/10.1016/i.jvb.2010.09.006

Taylor \& Pick (2008). The work orientations of Australian university students. Journal of Education \& Work, 21 (5), $405-421$.

D.O.I.: http://dx.doi.org/10.1080/13639080802583496

Teng, Chih-Ching (2008). The effect of personality traits and attitudes on student uptake in hospitality employment. International Journal of Hospitality Management. 27, 76-86.

D.O.I.: http://dx.doi.org/10.1016/j.ijhm.2007.07.007 
Tomlinson, M. (2007). Graduate employability and students attitudes and orientations to the labour market. Journal of Education and Work, 20(4), $285-304$.

D.O.I.: http://dx.doi.org/10.1080/13639080701650164

Trent, J. (2011). 'Four years on, I'm ready to teach': teacher education and the construction of teacher identities. Teachers and Teaching. $17(5), 529-543$.

D.O.I.: http://dx.doi.org/10.1080/13540602.201 1.602207

Turner, J. C. (1982). Towards a cognitive redefinition of the social group. In Tjfel, H. (ed), Social identity and intergroup relations (15-40). Cambridge: Cambridge University Press.

Watts, R. (1987). Development of professional identity in Black clinical psychology students. Professional Psychology: Research and Practice, 18, $28-35$.

D.O.I.: http://dx.doi.org/10.1037/0735-7028.18.1.28

Wegge, J., Schmidt, K., Parkes, C. \& van Dick, R. (2007). 'Taking a sickie': Job satisfaction and job involvement as iterative predictors of absenteeism in a public organization. Journal of Occupational and Organisational Psychology, 80, 77 - 89.

D.O.I.: http://dx.doi.org/10.1348/096317906X99371

Wenger, E. (1998). Communities of practice. Learning, meaning and, identity. Web definition. http://books.google.co.uk/books

Yong, B. C. S. (1995). Teacher trainees' motives for entering into a teaching career in Brunei Darussalam. Teaching and Teacher Education, 11(3), 275 -280. D.O.I.: http://dx.doi.org/10.1016/0742$\underline{051 \times(94) 00023-Y}$

\section{Sobre la autora:}

Bahijah Abas

bahijah.abas@stir.ac.uk

PhD student at University of Stirling, Institute of Socio-Management, Graduate Student. Research Interests: Social Identity, Teacher Identity Formation, Organizational Citizenship Behavior, and structure and agency debate in social science

\section{Para citar este artículo:}

Abas, B. (2014). Who am i this time? Exploring prospective teachers' attitudes towards the teaching profession in Malaysia. Revista Fuentes, 15, Junio, pp. 237-260. [Fecha de consulta: dd/mm/aaaa]. http://www.revistafuentes.es/

D.O.I.: http://dx.doi.org/10.12795/revistafuentes.2014.115.11 